\title{
Gender Wage Differences in the Czech Public Sector: A Micro-level Case
}

\section{Veronika Hedija ${ }^{1}$}

\begin{abstract}
The aim of this study is to estimate the unexplained gender pay gap in individual departments of a Czech hospital, to find out whether this gap varies between departments and, if so, to identify the possible causes of these differences. To estimate the unexplained part of the gender pay gap, we use the average treatment effect on the treated (ATT), and to identify the causes behind differences in the unexplained gender pay gap we use a linear regression model. We find that the ATT varies significantly between departments. To explain these differences, we use selected characteristics of the departments: the department's size, the proportion of women in the department, and the gender of the departmental head. We come to the conclusion that women's wages increase relative to male wages as the proportion of female employees grows. On the other hand, the unexplained gender wage gap is not proven to be lower in smaller or female-led departments.
\end{abstract}

Key words: Gender pay gap, Gender, Healthcare, Public sector, Wage differences

JEL Classification: I14, J16, J24, J71

Received: 12 August 2015 / Accepted: 15 March 2016 / Sent for Publication: 16 June 2016

\section{Introduction}

The existence of wage differences between men and women is a well-known fact. According to the Czech Statistical Office (2014), data from 2012 showed that women in the Czech Republic earned 78 percent of average male gross monthly earnings, with variation across the different sectors of the Czech economy. Using the CZ-NACE classification, these gender wage differences were found to be largest in groups K: Financial and insurance activities, Q: Human health and social care activities and J: Information and communication. Here, women earn less than 70 percent of the average male wage. Meanwhile, the lowest gender wage differences were identified in sector H: Transportation and storage, where female earnings amount to more than 95 percent of male earnings.

This data in itself gives no evidence as to the existence of wage discrimination against women. To a certain extent, gender wage disparity can be explained by observed differences in the characteristics of men and women. It is the part of the gender pay gap (GPG)

\footnotetext{
${ }^{1}$ Vysoké učení technické v Brně, Fakulta podnikatelská, Kolejní 2906/4, 61200 Brno, hedija@fbm.vutbr.cz.
}

C 2016 by the authors; licensee Review of Economic Perspectives / Národohospodárský obzor, Masaryk University, Faculty of Economics and Administration, Brno, Czech Republic. This article is an open access article distributed under the terms and conditions of the Creative Commons Attribution 3.0 license, Attribution - Non Commercial - No Derivatives. 
that remains unexplained despite these observable differences that is usually considered a measurement of wage discrimination against women. This is known as the remuneration effect, the effect of discrimination or most frequently simply as the unexplained gender pay gap. A number of empirical studies have been devoted to estimating the unexplained gender pay gap in the Czech Republic (Jurajda 2003, Mysíková 2012). These have shown that differences in the average characteristics of men and women only account for a small part of the raw gender pay gap, and that constant characteristics like occupation and sector are important factors in explaining disparities between male and female wages.

The unexplained gender pay gap also varies according to sector - public and private. Jurajda (2003) analysed the gender pay gap in the Czech and Slovak private and public sectors. He concluded that the unexplained gender pay gaps differed dramatically between these sectors. In the private sector it represented more than 60 percent of the raw gender pay gap, while in the public sector it amounted to approximately 40 percent of the raw gender pay gap. Hedija (2014) examined differences in the unexplained gender pay gap between different sectors of the Czech economy and concluded that the unexplained gender pay gap was lower in the public sector than in the private sector, although it was still present in the public sector. These differences may be explained by different wage setting mechanisms in the private and public sectors and the easier implementation of anti-discrimination policies in the public sector.

However the existing unexplained gender pay gap cannot be entirely attributed to wage discrimination against women; it only represents the upper limit. Part of the unexplained wage difference may be explained by differences in the unobserved characteristics of individuals (e.g. talent, work effort, loyalty) or by characteristics unavailable from official data (e.g. actual job content, responsibility). The second issue could be minor and is related to the use of detailed data from just one firm or selected firms. Hedija and Musil (2012) used data from a Czech hospital and conclude that the unexplained gender pay gap is negligible, as it amounts to only 2.6 percent. On the other hand, using data from a private sector company Hedija and Musil (2011) concluded that the different observable characteristics of men and women could explain only a small part of the gender pay gap, if any: they found the unexplained gender wage gap to be approximately 20 percent to the disadvantage of women.

Recently, studies have begun to appear that focus on identifying the causes behind variation in unexplained gender pay gaps. Arulampalam et al. (2007) and Christofides at al. (2013) analyse gender wage differences in selected European countries. They use the selected countries' specific policies aimed at reconciling work and family life and their wage-setting institutions to explain differences in gender pay gaps between the countries. They identify the relationship between the unexplained gender pay gap and country-specific policies and institutions. Hedija (2014) searches for the causes of the differences in unexplained gender pay gap within individual sectors of the Czech economy. Using a linear regression model with the proportion of women, the proportion of female managers, the proportion of small firms and ownership (public or private) as explanatory variables, she indicates that ownership and the proportion of women in management contribute significantly to variation in the unexplained gender wage gap. We have taken inspiration from these studies and use the maximum micro-level attitude. 
This study is devoted to wage differences between men and women working in a hospital. It aims to identify the unexplained gender pay gap in individual departments and to examine whether this varies and, if so, identify the possible causes behind the differences.

Like Hedija and Musil (2012), we use data from a Czech hospital; however in this case we use a different dataset (data from a larger hospital). Unlike previous studies, this study aims not only to detect the existence of potential wage discrimination against women in the selected firm but also to identify the causes of existing gender wage differences at the firm level.

The first section of the paper describes the data used and methods applied. In order to estimate the unexplained gender pay gap, we use the average treatment effect on the treated (ATT) and to identify the causes of differences in the unexplained gender pay gap we use a linear regression model. The second section reports the results obtained and discusses these, comparing them with conclusions reached by previous studies. We find that female wages increase relative to male wages as the proportion of female employees grows, and with female heads of department.

\section{Data and Methods}

We use data from a Czech hospital that was willing to provide us with the necessary information. The hospital in question is a large university hospital, which boasts over 2,000 beds and has more than 5,000 employees.

Table 1 Raw gender pay gap by occupation

\begin{tabular}{lccc} 
Occupation & $\begin{array}{c}\text { Number of em- } \\
\text { ployees }\end{array}$ & $\begin{array}{c}\text { Proportion of } \\
\text { women (\%) }\end{array}$ & $\begin{array}{c}\text { Raw gender pay } \\
\text { gap }\end{array}$ \\
\hline technical and economic worker & 499 & 78.2 & -0.293 \\
worker & 471 & 39.1 & -0.241 \\
pharmacist & 32 & 90.6 & 0.077 \\
pharmaceutical assistant & 42 & 100.0 & - \\
other professional & 166 & 80.7 & -0.034 \\
doctor & 928 & 56.7 & -0.167 \\
lower medical worker & 145 & 91.7 & -0.039 \\
midwife & 147 & 100.0 & - \\
orderly & 633 & 83.7 & -0.107 \\
paramedical worker & 718 & 95.1 & 0.170 \\
nurse & 1,639 & 97.1 & 0.092 \\
medical laboratory technician & 262 & 97.3 & 0.143 \\
Total & 5,682 & 81.7 & -0.157
\end{tabular}

Note: Raw gender pay gap is calculated as the difference between the logarithm of women's average hourly wage and the logarithm of men's average hourly wage in the given occupation. Source: Data from hospital, author's computations. 
The data provided is administrative in character, and dates back to 2010. Employees with long-term illnesses or who were on maternity or parental leave or working on a short-term contract were excluded from the sample. The following characteristics of the hospital's employees were measured: gender, age, highest level of education, occupation, number of years worked at the hospital, working time (where 1 indicates full time), department, hours worked per year, overtime hours, days of sick leave, days of annual leave and annual gross wage. The gross hourly wage is calculated as a ratio of the annual gross wage (including bonuses) and the sum of worked hours (including overtime) and hours of annual leave (days of annual leave* $8 *$ working time).

Our dataset enables us to identify 12 groups of employees working in more than 60 departments: worker, orderly, technical and economic worker, lower medical worker, medical laboratory technician, paramedical worker, nurse, midwife, pharmacist, pharmaceutical assistant, other professional, doctor. The number of employees and proportion of women in these individual occupations are shown in table 1.

Female employees dominate in most of the occupations, with the exception of workers. In seven cases women represent more than 90 percent of the employees in the given occupation (lower medical worker, medical laboratory technician, paramedical worker, nurse, midwife, pharmacist, pharmaceutical assistant).

In order to work with a relatively large and sample of men and women, and one that would be homogenous in terms of job content, we selected to work only with orderlies and doctors. These groups of employees are present in a large number of departments, while they also provide us with an interesting comparison between two occupations at the top and bottom of the hierarchy in terms of education and skills required.

Table 2 Observed characteristics of male and female orderlies

\begin{tabular}{lcc} 
Characteristic & Mean men & Mean women \\
\hline Age (year) & 39.74 & 43.57 \\
Education (\%) & & \\
- lower secondary & 14.56 & 26.1 \\
- upper secondary -without certificate & 0.00 & 0.34 \\
- upper secondary - with certificate & 42.72 & 53.04 \\
- upper secondary - school diploma & 37.86 & 19.93 \\
- tertiary - higher professional & 0.97 & 0 \\
- tertiary - bachelors level & 0.97 & 0 \\
- tertiary - masters and doctoral level & 2.91 & 0.68 \\
Full time & 0.98 & 0.98 \\
Years at the hospital & 8.29 & 8.34 \\
Sickness (days) & 5.93 & 10.73 \\
Overtime (hours) & 54.04 & 29.21 \\
Female manager (\%) & 41.75 & 15.20 \\
\hline N & 103 & 296
\end{tabular}

Source: Data from hospital. 
As we had set out to examine differences in the unexplained gender pay gap between individual departments, we excluded departments which had only male or only female orderlies and doctors. Our final data set covers 1279 employees (399 orderlies and 880 doctors) working in 45 departments. The average characteristics of these orderlies and doctors (divided by gender) are shown in tables 2 and 3 .

Table 3 Observed characteristics of male and female doctors

\begin{tabular}{lcc} 
Characteristic & Mean men & Mean women \\
\hline Age (year) & 40.33 & 38.10 \\
Education (\%) & & \\
- tertiary - masters and doctoral level & 100 & 100 \\
Full time & 0.63 & 0.66 \\
Years at the hospital & 11.57 & 10.74 \\
Sickness (days) & 5.03 & 14.30 \\
Overtime (hours) & 169.30 & 136.71 \\
Female manager (\%) & 13.49 & 21.91 \\
\hline $\mathrm{N}$ & 378 & 502 \\
\hline
\end{tabular}

Source: Data from hospital.

To identify the unexplained gender pay gap and find out whether it varies between departments, we estimate the unexplained gender pay gap at a department level using an estimation of the average treatment effect on the treated (ATT). To receive a maximum micro-level view, we estimate these separately for our two selected occupations: orderly and doctor.

The ATT is the average benefit resulting from being treated. In our case, the ATT is the mean effect for women in the form of a lower wage resulting from being a woman. We count the ATT for each department using the following calculation formula for ATT:

$$
A T T=E\left(y_{i}(1)-y_{i}(0) \mid T_{i}=1\right) \text {. }
$$

where $\mathrm{T}$ is the binary treatment indicator, $\mathrm{T}=1$ denotes treatment and $\mathrm{T}=0$ otherwise, $y(1)$ is the potential outcome with treatment and $y(0)$ is the potential outcome without treatment. In our case, being treated means being a woman. We can rewrite the ATT as:

$$
A T T=E\left(y_{i}(1) \mid T_{i}=1\right)-E\left(y_{i}(0) \mid T_{i}=1\right) .
$$

where ATT represents the gender pay gap that cannot be explained by the different characteristics of men and women. The term $E\left(y_{i}(1) \mid T_{i}=1\right)$ is the sample average of the logarithm of women's gross wages and $E\left(y_{i}(0) \mid T_{i}=1\right)$ is the sample average of the logarithm of what women's gross wages would be if they were men.

From our sample, we know the first term on the right hand side of equation 2, the sample average of the logarithm of women's hourly gross wages. The second term, the aver- 
age of the logarithm of what women's hourly gross wages would be if they were men, needs to be estimated. There are several possible ways of making such an estimate - for more details see Wooldridge (2002). We estimate this using coefficients of the male wage function

$$
\left(y_{i} \mid T_{i}=0\right)=\beta_{0} . X_{i}+u_{i} \text {. }
$$

where $y_{i}$ is the logarithm of the male gross hourly wage, $\beta_{0}$ is the vector of the coefficients of the wage function, $\mathrm{X}_{\mathrm{i}}$ is the vector of the chosen observed characteristics of men and $u_{i}$ is a disturbance term. In most departments the number of male employees (orderlies or doctors) is too small for us to be able to estimate the coefficients of the male wage function for each department separately and so we instead estimate the male wage function for the whole sample of male orderlies/doctors using department as one of the explanatory variables.

Apart from department (a dummy variable denoting the department where the employee works), the other explanatory variables used are: age (the age of the employee in years); education level (a dummy variable for the highest level the employee has attained); years in the firm (the number of years the employee has worked in the hospital), squared years in the firm, full time (a dummy variable for full time positions), sickness (the number of days the employee has spent on sick leave) and overtime hours (the number of overtime hours the employee works). The dummy variables used for the education level distinguish seven stages of education: lower secondary education, upper secondary vocational education without certificate, upper secondary vocational education with certificate, upper secondary education with school diploma, tertiary higher professional education, bachelors level tertiary education and masters and doctoral level tertiary education. The explanatory variable for education level is only used in the wage function for orderlies (because all doctors have the same level of education). The motivation for for the inclusion of the last two explanatory variables (sick leave and overtime hours) is the fact that more overtime hours and a smaller number of sick leave days are both associated with a higher average hourly wage.

The ATT is estimated as the difference between the average of the logarithm of women's gross hourly wages and the average of the predicted values of female wages computed using estimated coefficients for the male wage function.

$$
A T T=E\left(y_{i}(1) \mid T_{i}=1\right)-E\left(\beta_{0} \cdot X_{i} \mid T_{i}=1\right) \text {. }
$$

Where $E\left(\beta_{0} . X_{i} \mid T_{i}=1\right)$ is the mean of the predicted wages (the logarithm of the gross hourly wage) for every woman in the sample.

The estimated ATT represents the unexplained gender pay gap. The negative sign indicates that women receive relatively lower wages compared to men. The results obtained are the same as those found when using the Oaxaca-Blinder decomposition with men's wages as the equilibrium wage.

We estimate the ATT separately for each individual department at the hospital. To identify the possible causes of variation in the estimated ATT, we construct a linear regression model where we use the calculated ATT for the individual departments as the de- 
pendent variable. To explain variation in the unexplained gender pay gap between departments, we use similar control variables to those used in Hedija (2014), but at the departmental level: these are the gender composition of the department, the department size and a dummy for a female head of department.

$$
A T T_{j}=\alpha+\beta_{1} \text {. } \text { proportionofwomen }_{j}+\beta_{2} \cdot \text { femalemanager }_{j}+\beta_{3} . \text { size }_{j}+u_{j} .
$$

Where $j$ denotes the department, proportion of women $_{i}$ is the proportion of female orderlies/doctors working in the department, female manager $_{i}$ is a dummy variable for the department having a female head, size denotes the number of employees in the department, and $u_{j}$ is the disturbance term.

The unexplained gender pay gap may be affected to some extent by the proportion of women in the department: the unexplained pay gap between male and female employees in the same position could be lower in departments with either a very low or very high proportion of female representatives. Women may have more male characteristics in departments with a low proportion of women; they might then be perceived as men and this might be reflected in their salary. The same could be valid for men working as orderlies/doctors in departments with a dominant share of female orderlies/doctors. We use a dummy for the proportion of female orderlies/doctors, which distinguishes three groups: departments with 0-20 percent female orderlies/doctors, departments with 40-80 percent female orderlies/doctors, and departments with more than 80 percent female orderlies/doctors.

The unexplained gender pay gap could be lower in female-led departments. Some empirical studies have confirmed that the presence of a female manager leads to a decrease in gender pay gap (Hultin and Szulkin 1999 and 2003, Cardoso and Winter-Ebmer 2010, Hedija 2015). These conclusions are in accordance with the social identity theory that states that individuals tend to favour members of their own group over members of other groups (Tajfel 1982, Tajfel and Turner 1979). Appling this theory to remuneration, female heads of department may evaluate female employees better than male employees. Hence, we use a dummy for a female head of department as one of our control variables. When examining the impact of the manager's gender on wage discrimination against women, it is essential to take into consideration managers' wage-setting powers. In the Czech public health sector, wages are regulated by Government Regulation No. $564 / 2006$ on the salaries of employees in public service and administration. This regulation defines wage classes and grades, assigns workers to these, and sets the base gross wage for each class and grade. There is no regulated maximum for bonuses, and at the hospital we are studying, bonuses are not even controlled by any internal regulations. This means that an employee's actual gross wage, including bonuses, depends on the bonuses granted by the head of department, who is solely limited in their allocation by the size of budget available in that department. In other words, in this case, heads of department have relative flexibility in wage formation.

Unexplained gender pay differences could also be lower in small departments than in larger ones, because employees tend to know each other better in small departments and may also be inclined to disclose information about their wages. In such cases, it would be harder for managers to discriminate between women's and men's wages while main- 
taining a good working environment and good relationships in the department. This is why we use a dummy for department size (number of employees).

To estimate the coefficients of the model we used the OLS estimator with robust standard errors.

\section{Results and Discussion}

Using equation 4 we estimate the average treatment effect on the treated for each department at the hospital. We estimate these separately for orderlies and doctors. The results are shown in table 4, where beside the ATT we also report the raw gender pay gap, calculated as the difference between the logarithm of the average hourly wage of female orderlies/doctors and the logarithm of the average hourly wage of male orderlies/doctors. The ATT results represent the unexplained gender pay gap. The negative sign indicates that women receive relatively lower wages than men.

Table 4 Raw gender pay gap and average treatment effect on the treated

\begin{tabular}{ccccc|ccccc}
\multicolumn{4}{c}{ orderlies } & \multicolumn{2}{c}{ doctors } & \multicolumn{2}{c}{ orderlies } & \multicolumn{2}{c}{ doctors } \\
\hline Dep & Raw & ATT & Raw & ATT & Dep & Raw & ATT & Raw & ATT \\
& GPG & & GPG & & & GPG & & GPG & \\
\hline 1 & -0.307 & -0.233 & - & - & 24 & - & - & 0.120 & 0.138 \\
2 & 0.136 & 0.048 & -0.222 & -0.057 & 25 & 0.156 & 0.092 & -0.168 & -0.015 \\
3 & -0.079 & -0.028 & -0.219 & -0.023 & 26 & - & - & -0.443 & 0.031 \\
4 & - & - & -0.100 & 0.040 & 27 & -0.085 & -0.065 & - & - \\
5 & - & - & 0.028 & 0.097 & 28 & -0.011 & -0.067 & - & - \\
6 & 0.092 & 0.039 & 0.000 & -0.051 & 29 & - & - & 0.200 & 0.074 \\
7 & 0.216 & 0.182 & 0.226 & 0.390 & 30 & - & - & 0.166 & 0.134 \\
8 & -0.071 & -0.154 & -0.305 & -0.113 & 31 & 0.166 & 0.138 & -0.319 & -0.168 \\
9 & - & - & -0.156 & -0.111 & 32 & - & - & -0.151 & -0.207 \\
10 & 0.243 & 0.205 & -0.108 & -0.060 & 33 & - & - & 0.033 & 0.057 \\
11 & - & - & -0.234 & -0.132 & 34 & - & - & 0.538 & 0.092 \\
12 & 0.061 & -0.022 & -0.129 & -0.149 & 35 & - & - & -0.214 & 0.019 \\
13 & -0.100 & 0.010 & -0.374 & 0.008 & 36 & - & - & 0.110 & 0.103 \\
14 & - & - & -0.196 & -0.049 & 37 & - & - & -0.011 & 0.004 \\
15 & - & - & -0.213 & 0.018 & 38 & - & - & -0.266 & 0.052 \\
16 & - & - & 0.068 & 0.037 & 39 & - & - & -0.345 & -0.044 \\
17 & - & - & -0.001 & 0.014 & 40 & - & - & -0.123 & -0.188 \\
18 & - & - & 0.484 & 0.641 & 41 & - & - & 0.019 & 0.128 \\
19 & 0.161 & 0.194 & 0.027 & 0.016 & 42 & - & - & -0.234 & -0.066 \\
20 & - & - & -0.097 & 0.094 & 43 & -0.197 & -0.179 & -0.290 & -0.152 \\
21 & - & - & -0.040 & -0.120 & 44 & - & - & 0.052 & 0.015 \\
22 & -0.079 & -0.072 & - & - & 45 & 0.297 & 0.331 & - & - \\
23 & 0.201 & -0.156 & 0.001 & 0.177 & & & & & \\
\hline
\end{tabular}

Source: Author's computations.

The department-specific ATT results are lower (in absolute value) than the raw gender pay gap in most cases; this means that differences in characteristics between men and women explain part of the raw gender wage difference. Nevertheless, part of the raw wage difference between male and female employees remains unexplained in some 
departments, both for orderlies and doctors, and this phenomenon is quite varied in extent. Furthermore, in most cases, the ATT result varies for orderlies and doctors working in the same departments.

Where orderlies are concerned, the estimated ATT ranges from -0.233 for department 1 to 0.331 for department 45 . This indicates that male orderlies earn about 23 percent more than female orderlies in department 1 , while in department 45 female orderlies earn about 33 percent more than their male counterparts; these differences cannot be explained by the known observed characteristics of the men and women concerned (their age, education level, number of years at the hospital, sickness leave, overtime hours and working time). The estimated ATT was positive in nine of the eighteen departments examined that employ at least one male orderly. This indicates that in half the examined departments, female orderlies earn more than their male co-workers with similar observed characteristics. The situation for doctors is very similar: the ATT ranges from -0.207 for department 32 to 0.641 for department 18 , and is positive in twenty three out of forty departments (more than half).

Table 5 Linear regression model - orderlies

\begin{tabular}{|c|c|c|c|c|c|}
\hline Model & (1) & (2) & (3) & (4) & (5) \\
\hline \multicolumn{6}{|l|}{ Size } \\
\hline - 50-100 employees & $\begin{array}{c}-0.320^{\star \star *} \\
(0.056)\end{array}$ & $\begin{array}{c}-0.378^{\star * *} \\
(0.030)\end{array}$ & $\begin{array}{r}-0.417^{* * *} \\
(0.069)\end{array}$ & $\begin{array}{c}-0.405^{\star * *} \\
(0.049)\end{array}$ & $\begin{array}{c}-0.466^{* * *} \\
(0.089)\end{array}$ \\
\hline - 100-150 employees & $\begin{array}{c}-0.312^{* * *} \\
(0.077)\end{array}$ & $\begin{array}{c}-0.349^{* * *} \\
(0.093)\end{array}$ & $\begin{array}{c}-0.349^{* * *} \\
(0.097)\end{array}$ & $\begin{array}{c}-0.364^{* * *} \\
(0.048)\end{array}$ & $\begin{array}{c}-0.390^{* * *} \\
(0.057)\end{array}$ \\
\hline$-150+$ employees & $\begin{array}{c}-0.381^{* * *} \\
(0.038)\end{array}$ & $\begin{array}{c}-0.398^{* * *} \\
(0.046)\end{array}$ & $\begin{array}{c}-0.398^{* * *} \\
(0.048)\end{array}$ & $\begin{array}{c}-0.431^{* * *} \\
(0.042)\end{array}$ & $\begin{array}{c}-0.442^{* * *} \\
(0.047)\end{array}$ \\
\hline \multicolumn{6}{|l|}{ Proportion of women } \\
\hline $\begin{array}{l}\text { - 0-20 percent female } \\
\text { orderlies }\end{array}$ & - & $\begin{array}{l}-0.215^{\star *} \\
(0.093)\end{array}$ & $\begin{array}{l}-0.292 \\
(0.164)\end{array}$ & - & - \\
\hline $\begin{array}{l}-80+\text { percent female } \\
\text { orderlies }\end{array}$ & - & $\begin{array}{l}0.087 \\
(0.058)\end{array}$ & $\begin{array}{c}0.087 \\
(0.061)\end{array}$ & - & - \\
\hline $\begin{array}{l}\text { Proportion of women } \\
\text { (orderlies) }\end{array}$ & - & - & - & $\begin{array}{l}0.443^{\star * *} \\
(0.089)\end{array}$ & $\begin{array}{l}0.542^{* * *} \\
(0.124)\end{array}$ \\
\hline Female manager & - & - & $\begin{array}{l}0.077 \\
(0.105)\end{array}$ & - & $\begin{array}{l}0.084 \\
(0.084)\end{array}$ \\
\hline Constant & $\begin{array}{l}0.331^{* * *} \\
(0.000)\end{array}$ & $\begin{array}{l}0.331^{* * *} \\
(0.000)\end{array}$ & $\begin{array}{l}0.331^{* * *} \\
(0.000)\end{array}$ & $\begin{array}{l}0.036 \\
(0.060)\end{array}$ & $\begin{array}{l}-0.030 \\
(0.083)\end{array}$ \\
\hline $\mathrm{R}^{2}$ & 0.303 & 0.534 & 0.557 & 0.556 & 0.584 \\
\hline $\mathrm{N}$ & 18 & 18 & 18 & 18 & 18 \\
\hline
\end{tabular}

Note: ${ }^{* * *}$ significant at the 1 per cent level, ${ }^{* *}$ significant at the 5 per cent level, *significant at the 10 per cent level, robust standard errors in brackets

Source: Author's computations. 
If we focus only on departments that employ both doctors and orderlies, we observe that the ATT is only similar for doctors and orderlies in four such departments and that in many cases, orderlies take positive values of ATT and doctors negative values. This fact either indicates the existence of wage discrimination against male orderlies and female doctors, or an unobservable higher quality among female orderlies and male doctors in comparison to their co-workers of the opposite gender.

We use a linear regression model (equation 5) to identify the causes of the differences in unexplained gender pay gap between the departments. Tables 5 and 6 present the results. We test the size of the department, the proportion of women in the department and the gender of the head of department as factors that might explain disparities in the departmental ATT results.

Table 6 Linear regression model - doctors

\begin{tabular}{|c|c|c|c|c|c|}
\hline Model & (1) & (2) & (3) & (4) & (5) \\
\hline \multicolumn{6}{|l|}{ Size } \\
\hline - 50-100 employees & $\begin{array}{c}0.006 \\
(0.050)\end{array}$ & $\begin{array}{c}0.040 \\
(0.053)\end{array}$ & $\begin{array}{c}0.046 \\
(0.054)\end{array}$ & $\begin{array}{c}0.000 \\
(0.051)\end{array}$ & $\begin{array}{c}0.007 \\
(0.053)\end{array}$ \\
\hline - 100-150 employees & $\begin{array}{c}0.017 \\
(0.071)\end{array}$ & $\begin{array}{c}0.047 \\
(0.069)\end{array}$ & $\begin{array}{c}0.059 \\
(0.074)\end{array}$ & $\begin{array}{c}0.054 \\
(0.091)\end{array}$ & $\begin{array}{r}0.062 \\
(0.096)\end{array}$ \\
\hline - $150+$ employees & $\begin{array}{c}-0.124^{* * *} \\
(0.044)\end{array}$ & $\begin{array}{l}-0.069 \\
(0.056)\end{array}$ & $\begin{array}{l}-0.044 \\
(0.066)\end{array}$ & $\begin{array}{l}-0.126^{* *} \\
(0.055)\end{array}$ & $\begin{array}{l}-0.101^{*} \\
(0.059)\end{array}$ \\
\hline \multicolumn{6}{|l|}{ Proportion of women } \\
\hline $\begin{array}{l}\text { - 0-20 percent female } \\
\text { doctors }\end{array}$ & - & $\begin{array}{l}-0.001 \\
(0.086)\end{array}$ & $\begin{array}{c}0.016 \\
(0.090)\end{array}$ & - & - \\
\hline $\begin{array}{l}-80+\text { percent female } \\
\text { doctors }\end{array}$ & - & $\begin{array}{l}0.279^{* *} \\
(0.130)\end{array}$ & $\begin{array}{l}0.268^{* *} \\
(0.113)\end{array}$ & - & - \\
\hline $\begin{array}{l}\text { Proportion of women } \\
\text { (doctors) }\end{array}$ & - & - & - & $\begin{array}{c}0.267 \\
(0.200)\end{array}$ & $\begin{array}{r}0.229 \\
(0.168)\end{array}$ \\
\hline Female manager & - & - & $\begin{array}{c}0.064 \\
(0.584)\end{array}$ & - & $\begin{array}{r}0.063 \\
(0.070)\end{array}$ \\
\hline Constant & $\begin{array}{c}0.029 \\
(0.027) \\
\end{array}$ & $\begin{array}{l}-0.027 \\
(0.044)\end{array}$ & $\begin{array}{l}-0.052 \\
(0.055)\end{array}$ & $\begin{array}{l}-0.134 \\
(0.136)\end{array}$ & $\begin{array}{l}-0.136 \\
(0.136)\end{array}$ \\
\hline $\mathrm{R}^{2}$ & 0.099 & 0.390 & 0.419 & 0.203 & 0.230 \\
\hline $\mathrm{N}$ & 40 & 40 & 40 & 40 & 40 \\
\hline
\end{tabular}

Note: ${ }^{* * *}$ significant at the 1 per cent level, ${ }^{* *}$ significant at the 5 per cent level, ${ }^{*}$ significant at the 10 per cent level, robust standard errors in brackets

Source: Author's computations. 
Departmental size is measured by the department's total number of employees, in four size categories. ${ }^{2}$ The results for orderlies and doctors are very similar. The disparity in orderlies' earnings to the disadvantage to female orderlies increases significantly (i.e. the ATT decreases) in all three size categories compared with the lowest size departments (which have fewer than 50 employees), although the effect of departmental size does not increase as departments grow beyond 100 employees. For doctors, a statistically significant increase in unexplained gender pay gap (decreased ATT) is only detected in departments with more than 150 employees (the largest size category).

To examine the effect of the proportion of female orderlies/doctors in the department on variation in ATT among departments, we use dummy variables for three groups of departments: those with less than 20 percent female orderlies/doctors, those with 20 to 80 percent female orderlies/doctors and those with more than 80 percent female orderlies/doctors. ${ }^{3}$ Model 2 in table 5 shows the results for orderlies and model 2 in table 6 shows the results for doctors. The ATT is lower in departments with less than 20 percent female orderlies, which indicates a higher unexplained gender pay gap in these cases compared with departments consisting of 20-80 percent female orderlies. In the case of departments with more than 80 percent female orderlies the effect is not significant. The situation is different for doctors: the ATT increases significantly in departments with more than 80 percent female doctors which indicates that in these departments there is lower potential wage discrimination against women.

There is no clear evidence that gender wage differences are lower in departments with an extremely high or low proportion of female employees. However, in both cases (and especially for doctors) the ATT tends to increase with an increase in the proportion of female employees (orderlies/doctors). Hence, we replace the previously-used dummy variable with the actual proportion of female orderlies/doctors (model 4 in tables 5 and 6 ). The results show that a 10 percentage point increase in the proportion of female orderlies decreases the unexplained gender pay gap (increases the ATT) by 4.4 percentage points, while a 10 percentage point increase in the proportion of female doctors decreases the unexplained gender pay gap (increases the ATT) by 2.7 percentage points, although this latter result is not statistically significant. These results are different from those reported in Hedija (2014) on the effect of the proportion of women on the unexplained gender pay gap within individual sectors of the Czech economy, where the effect was shown to be negligible. This could be due to the fact that the proportion of women was not studied at the individual firm or department level but only at the level of whole industries.

Finally we report the results of the model estimation using a dummy variable for a female head of department (models 3 and 5 in tables 5 and 6). Having a female head of department increases the ATT by approximately 8 percentage points for orderlies and

\footnotetext{
${ }^{2}$ We also tested the number of orderlies/doctors in the department as an explanatory variable but this did not prove to be a statistically significant factor in explaining differences in the ATT.

${ }^{3} \mathrm{We}$ also tried using the proportion of female employees (in all positions) in the department as an explanatory variable, but found that this was not statistically significant.
} 
by 6 percentage points for doctors. These findings are consistent with Hultin and Szulkin (1999 and 2003), Cohen and Huffman (2007), Cardoso and Winter-Ebmer (2010) and Hedija (2015), all of whom concluded that the gender wage gap is reduced with an increase in female management. However, in our case, these results are not found to be statistically significant.

\section{Conclusion}

The aim of this study was to identify the unexplained gender pay gap in individual departments of a Czech hospital, to find out whether this varies across the departments, and if so, to identify the possible causes behind these differences.

To receive a maximum micro-level view we focused on just two occupations within the hospital: orderlies and doctors. Firstly, we estimated the unexplained gender pay gap between male and female orderlies and doctors at the selected hospital using an estimation of the ATT. We found that the estimated ATT varied significantly between departments, ranging from -0.233 to 0.331 for orderlies and -0.207 to 0.641 for doctors. The ATT results proved to be positive in approximately half the departments (for both occupations), which indicates that female orderlies/doctors earn more than their male coworkers with similar observed characteristics in half the departments examined, and vice versa.

We then went on to use a linear regression model to identify the possible causes of the differences in ATT between the departments. We used department size, the proportion of female orderlies/doctors in the department and the gender of the head of department as control variables. Our results showed that the unexplained gender pay gap decreased (the ATT increased) with an increase in the proportion of female employees. A 10 percentage point increase in the proportion of female orderlies decreased the unexplained gender pay gap (increased the ATT) by approximately 5 percentage points. The effect was slightly weaker for doctors: a 10 percentage point increase in the proportion of female doctors in a given department decreased the unexplained gender pay gap by just 2 percentage points, and this result was not statistically significant. The unexplained gender pay gap also declined when the head of department was female: a female head of department leads to an increase in women's wages in relation to those of their male coworkers by 8 percent for orderlies and 6 percent for doctors. Nevertheless, these results were also not statistically significant. Finally, our results partly confirm the idea that wage differences between men and women increase with growth in departmental. We identified a statistically significant effect (for both orderlies and doctors) in departments with more than 150 employees.

Finally, we can conclude that our findings were very similar for both orderlies and doctors: in both cases, larger departments, higher proportions of female employees, and having a female head of department all resulted in decreasing the unexplained gender pay gap. However, the effect of female managers was statistically insignificant in both cases, and the effect of the proportion of female employees was weaker and not statistically significant for doctors.

Our study used detailed data from a single hospital to investigate gender pay gaps at departmental level. This enabled us to identify the effect of the head of department and 
to minimize bias from different job contents in similar occupations. Using data for a select group of employees - only orderlies and doctors - enabled us to minimize the effects on unexplained gender pay gap that might result from differences between particular hospital occupations, and enabled us to make a comparison of the results between an occupation with low education and skills requirements, and one with extremely high requirements. On the other hand, using data from only one hospital (one company) reduces the explanatory power of our results, which may not be valid across the Czech healthcare industry as a whole.

Funding: This paper was supported by internal grant No. FP-S-15-2877 entitled "The Selected Aspects of Financial Management in International Environment" at the Faculty of Business and Management, Brno University of Technology.

Disclosure statement: No potential conflict of interest was reported by the author.

\section{References}

ARULAMPALAM, W., BOOTH, A. \& BRYAN, M. (2007) Is there a glass ceiling over Europe? Exploring the gender pay gap across the wage distribution. Industrial \& Labor Relations Review. 62(2). p. 163-186. DOI: 10.1177/001979390706000201

CARDOSO, A. R. \& WINTER-EBMER, R. (2010) Female-Led Firms and Gender Wage Policies. Industrial and Labour Relations Review. 64(1). p. 143-163.

CHRISTOFIDES, L. N., POLYCARPOU, A. \& VRACHIMIS, K. (2013)Gender wage gaps, 'sticky floors' and 'glass ceilings' in Europe. Labour Economics. 21(April 2013). p. $86-102$.

COHEN, P. \& HUFFMAN, M. (2007) Working for the Woman? Female Managers and the Gender Wage Gap. American Sociological Review. 72(5). p. 681-704. DOI: $10.1177 / 000312240707200502$

Czech Statistical Office (2014) [online] Zaostřeno na ženy a muže 2013. [cit.20.9.2014]. Available on: http://www.czso.cz/csu/2013edicniplan.nsf/publ/1413-13-r_2013

HEDIJA, V. \& MUSIL, P. (2012) Gender wage differences in the selected Czech public sector company. Acta Universitatis Agricultura et Silviculturae Mendelianae Brunensis. 60(7). p. 81-88.

HEDIJA, V. \& MUSIL, P. (2011) Gender pay gap - application in the specific enterprise. Národohospodářský obzor/Review of Economic Perspectives. 11(4). p. 223-236.

HEDIJA, V. (2014) Gender Pay Gap in Different Sectors of Czech Economy. In 32nd International Conference MME 2014. Olomouc: Palacky University. p. 275280.

HEDIJA, V. (2015) The Effect of Female Managers on Gender Wage Differences. Prague Economic Papers. 24(1). p. 38-59. 
HULTIN, M. \& SZULKIN, R. (1999) Wages and Unequal Access to Organizational Power: An Empirical Test of Gender Discrimination. Administrative Science Quarterly. 44(3). p. 453-472. DOI: $10.2307 / 2666958$

HULTIN, M. \& SZULKIN, R. (2003) Mechanisms of Inequality Unequal Access to Organizational Power and the Gender Wage Gap. European Sociological Review. 19(2). p. 143-159. DOI: $\underline{10.1093 / \text { esr/19.2.143 }}$

JURAJDA, S. (2003) Gender Wage Gap and Segregation in Enterprises and the Public Sector in Late Transition Countries. Journal of Comparative Economics. 31 (2). p. 199222. DOI: $10.1016 / \mathrm{S} 0147-5967(03) 00040-4$

MYSÍKOVÁ, M. (2012) Gender Wage Gap in the Czech Republic and Central European Countries. Prague Economic Papers. 2012/3(3). p. 328-346.

TAJFEL, H. \& TURNER, J. C. (1979) An Integrative Theory of Intergroup Conflict. In The Social Psychology of Intergroup Relations. Monterey, CA: Brooks-Cole. p. 33-47.

TAJFEL, H. (1982) Social Psychology of Intergroup Relations. Annual Review of Psychology. 33(1). p. 1-39. DOI: 10.1146/annurev.ps.33.020182.000245

WOOLDRIDGE, J. (2002) Econometric Analysis of Cross Section and Panel Data. Cambridge: MIT Press. 